\title{
Trophic strategy of Atlantirivulus riograndensis (Cyprinodontiformes: Rivulidae), a non-annual rivulid threatened by extinction, in a perennial environment, Brazil)
}

\author{
Laísa Wociechoski Cavalheiro and Clarice Bernhardt Fialho
}

\begin{abstract}
Rivulidae includes non-annual fish of perennial habitats and annual fish of temporary wetlands. The objective of this research was to investigate the trophic strategy of Atlantirivulus riograndensis in a perennial environment. Sampling occurred in an environmental conservation unit in the Pampa biome, Brazil. Quantification of the diet followed the volumetric method. Consumption of autochthonous material as the main food source of the species followed the pattern of Rivulidae. Species is zooplanktonic when young. Food spectrum is broadened and insectivorousness increases with ontogeny, revealing a specialist trend in the feeding strategy of $A$. riograndensis. The most diverse feeding occurs in the spring and summer seasons in which the presence of larger fish was more frequent than in other seasons. The increased consumption of microcrustaceans in the fall was related to smaller individuals, captured in greater quantities in this post-reproductive period. The lowest diversity of dietary items occurs during the winter and may reflect the lower diversity of food resources available in this season or the transition from juvenile to adult diet, with consumption of autochthonous Diptera by medium sized fish.
\end{abstract}

Rivulidae inclui peixes não anuais de habitats perenes e peixes anuais de alagados temporários. O objetivo desta pesquisa foi investigar a estratégia trófica de Atlantirivulus riograndensis em um ambiente perene. A amostragem ocorreu em uma unidade de conservação ambiental no bioma Pampa, Brasil. A quantificação da dieta seguiu o método volumétrico. O consumo de material autóctone como principal recurso alimentar da espécie seguiu o padrão da família Rivulidae. A espécie é zooplanctívora quando juvenil. $\mathrm{O}$ espectro alimentar é ampliado e a tendência à insetivoria aumenta com a ontogenia, revelando traços especialistas na estratégia alimentar de A. riograndensis. A alimentação mais diversificada ocorreu na primavera e no verão, estações em que a presença dos peixes maiores foi frequente que em outras estações. $O$ aumento no consumo de microcrustáceos no inverno foi relacionado aos indivíduos menores, capturados em maior quantidade neste período pós-reprodutivo. A menor diversidade de itens alimentares ocorreu durante o inverno e pode refletir uma menor diversidade de recursos alimentares disponíveis nesta época do ano ou a transição da dieta de juvenil para adulto, com consumo de Diptera autóctone por peixes de tamanho médio.

Keywords: Autochthonous resources, Ontogeny, Seasonality, Specialist, Trophic pattern.

\section{Introduction}

Habitats like swamps, marshes, and wetlands that present seasonal fluctuations in water levels can simply reduce or enlarge their extensions, characterizing perennial habitats for fish populations. Alternatively, the environment can dry up completely during the period of low rainfall, creating seasonal habitats (Lake, 2003; Mas-Martí et al., 2010; Hinojosa-Garro et al., 2013). The hydroperiod restrict the spatial distribution of ichthyofauna when the water levels fall or determine the existence of a community composed of species with the ability to sustain viable populations even in seasonal habitats (DeAngelis et al., 2010).

Cyprinodontiformes are small fish and live in shallow, seasonal, or perennial aquatic environments that are between ten centimeters and one meter deep (Costa, 2009). The Rivulidae family is the most diverse in this group, with about 409 valid species distributed between southern Florida and northeastern Argentina (Costa, 2009, 2011; Eschmeyer \& Fong, 2015). Some non-annual rivulids are associated to perennial wetlands (Costa, 2011) which seasonally decrease in water level, representing stress conditions to fish populations.

Universidade Federal do Rio Grande do Sul, Departamento de Zoologia, Programa de Pós-Graduação em Biologia Animal, Avenida Bento Gonçalves 9500, Prédio 43435, CEP 91501-970 Porto Alegre, RS, Brazil. (LWC) isa_woci@hotmail.com (corresponding author), (CBF) cbfialho@via-rs.net 
Same dynamics of hydrology that affects the diversity of the ichthyofauna also acts decisively in the composition of food resources available to fish that, in turn, influence the spatial and temporal distribution of these species and their feeding strategies (Gerking, 1994; Lowe-McConnell, 1999). A well defined seasonality can promote modifications of habitat interfering in the availability of resources and consequently in the feeding of the species (Gerking, 1994).

Generalist strategy in the Rivulidae family is reported for annual fish classified as generalist top predators in temporary pond ecosystems found in the wetlands of southeastern Uruguay (Laufer et al., 2009). The feeding pattern found for rivulids consists of consumption of autochthonous items, with ingestion of non-aquatic prey in certain cases (Laufer et al., 2009; Abilhoa et al., 2010a, 2010b). For the genus Atlantirivulus in perennial coastal streams in the Mata Atlântica biome of southern Brazil, there are records of insectivorous or omnivorous dietary habits (Abilhoa et al., 2010a, 2010b). The wide availability of food resources follows seasonal and/or spatial trends (Lowe-McConnell, 1999; Abelha et al., 2001).

Using these resources is related to the trophic plasticity of the species and is also a determining factor in the reproductive success of the populations (Abelha et al., 2001). Additionally, the presence of a defined reproductive season can influence the feeding behavior of the species, like when modifications in feeding intensity (quantity of food ingested) occur or when ontogenetic biases appear due to alterations in the frequency of occurrence of youth and adults present in the population (Lowe-McConnell, 1999).

Feeding strategy employed in the pursuit of obtaining energy varies according to species and habitat (Wootton, 1990; Gerking, 1994). Specialist trends in stream fish were observed in stable hydrological systems in Wisconsin and Minnesota (in the United States), while in hydrologically variable stream ecosystems species appear to be more tolerant and to have increased trophic and habitat generalism (Poff \& Allan, 1995). Likewise, a generalist feeding behavior has been identified in fish from seasonal pools in the Yucatan Peninsula, Mexico, contrasting specialist diets in populations of perennial habitats (Hinojosa-Garro et al., 2013).

Atlantirivulus includes eleven small species (25-45 $\mathrm{mm}$ standard length) distributed in eastern Brazilian coastal drainages from the state of Bahia down to Rio Grande do Sul in the Mata Atlântica biome, constituting a wide geographical range. Atlantirivulus riograndensis (Costa \& Lanés, 2009) is registered further south, corresponding to the Pampa biome (Costa, 2011). This species is included on the list of species threatened by extinction, officially recognized by decree number 51,797, from September $8^{\text {th }}, 2014$ in the state of Rio Grande do Sul, and classified as endangered, according to the evaluation criteria defined by the International
Union for Natural Conservation (Fundação Zoobotânica do Rio Grande do Sul (FZB), 2014).

Knowledge of the feeding strategy of $A$. riograndensis in preserved habitats (like the Banhado dos Pachecos wildlife refuge) contributes to understanding its population dynamic, the origin of the resources used by the species, and its role in the food chain. Moreover, this study can serve as a basis for comparison with other non-annual and annual rivulids, permitting the identification of dietary patterns that repeat or differ, independent of inhabiting distinct biomes or unsimilar places like perennial wetlands or seasonal pools.

The aim of this study was to investigate the trophic strategy of $A$. riograndensis, a non-annual rivulid threatened by extinction, in a perennial, preserved environment in the Pampa biome, Brazil.

Following hypotheses are tested in this study: (i) the species follows the pattern of other rivulids, feeding on autochthonous items with seasonal changes in the diet composition; (ii) due to the ontogenetic changes in the feeding behavior, seasonal changes on the diet composition of this species are influenced by variations on the population size structure.

\section{Material and Methods}

Study area. Samples of $A$. riograndensis were taken in perennial preserved wetlands on the edge of swampy woods in the Banhado dos Pachecos wildlife reserve near the city of Viamão, state of Rio Grande do Sul, Brazil. This site is part of the Banhado Grande Area of Environmental Protection, belonging to the hydrographic basin of Laguna dos Patos (Fig. 1). The Refuge was established as a conservation unit in 2002 and covers an area of 2543.46 ha. of which 1455 ha. are marsh habitats, 384.8 ha. include wooded pine formations, 244.4 ha. are sandy forest and 459.8 ha. are dry fields or exposed soil (Accordi, 2008). Banhado dos Pachecos is an integral part of the Pampa biome which, in Brazil, is located exclusively in the state Rio Grande do Sul, between $34^{\circ}$ and $30^{\circ}$ latitude South and $57^{\circ}$ and $63^{\circ}$ longitude West.

Areas of occurrence of A. riograndensis in the Pampa biome consist of areas sensitive to pressures such as fragmentation, distortion of plant formations and conversion of land for cattle farming, agriculture and forestry (Pillar et al., 2012). Conservation records of the Pampa biome indicate that by the year 2005 there were only $25 \%$ of the original plant formations of this biome (Pillar et al., 2012).

The collection point $\left(30^{\circ} 05^{\prime} 44^{\prime \prime} \mathrm{S} 50^{\circ} 50^{\prime} 59^{\prime \prime} \mathrm{W}\right)$ of $A$. riograndensis in the Banhado dos Pachecos corresponds to an area of three to four meters wide with turbid water surrounded by swampy forest. Depth varies from ten centimeters to a meter and a half across different seasons. The substrate is muddy and there are large quantities of submersed, emergent, floating and marginal vegetation (Fig. 2). 

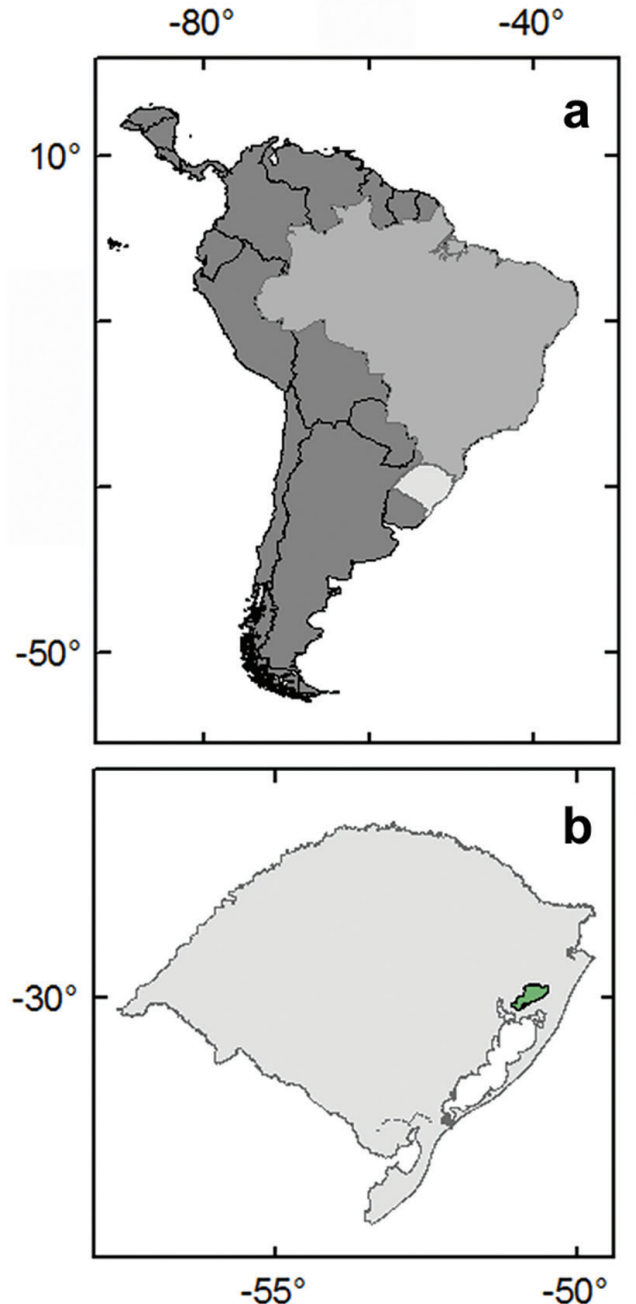

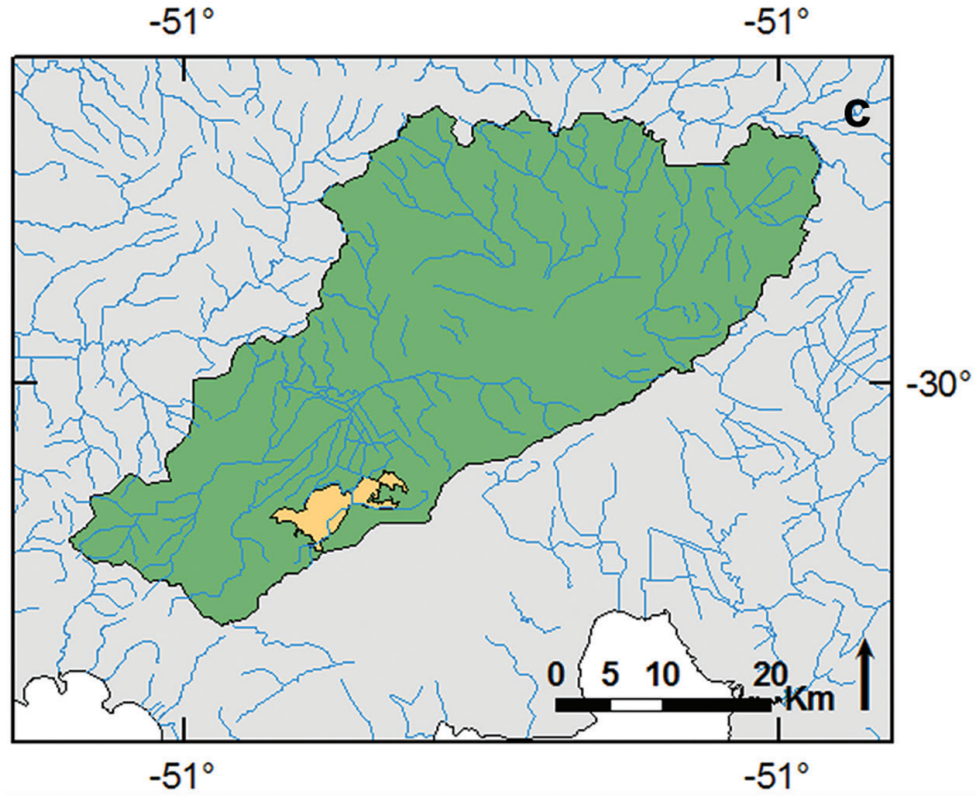

Hydrography

$\square$ Banhado Grande complex of wetlands

$\square$ Banhado dos Pachecos Wildlife Refuge

\section{Rio Grande do Sul state}

Fig. 1. Geographic location of the capture area of Atlantirivulus riograndensis. Geographical representation of South America, especially (a) Brazilian territory, (b) the state of Rio Grande do Sul and (c) Banhado dos Pachecos wildlife refuge in the city of Viamão, sampling area of Atlantirivulus riograndensis in 2012.

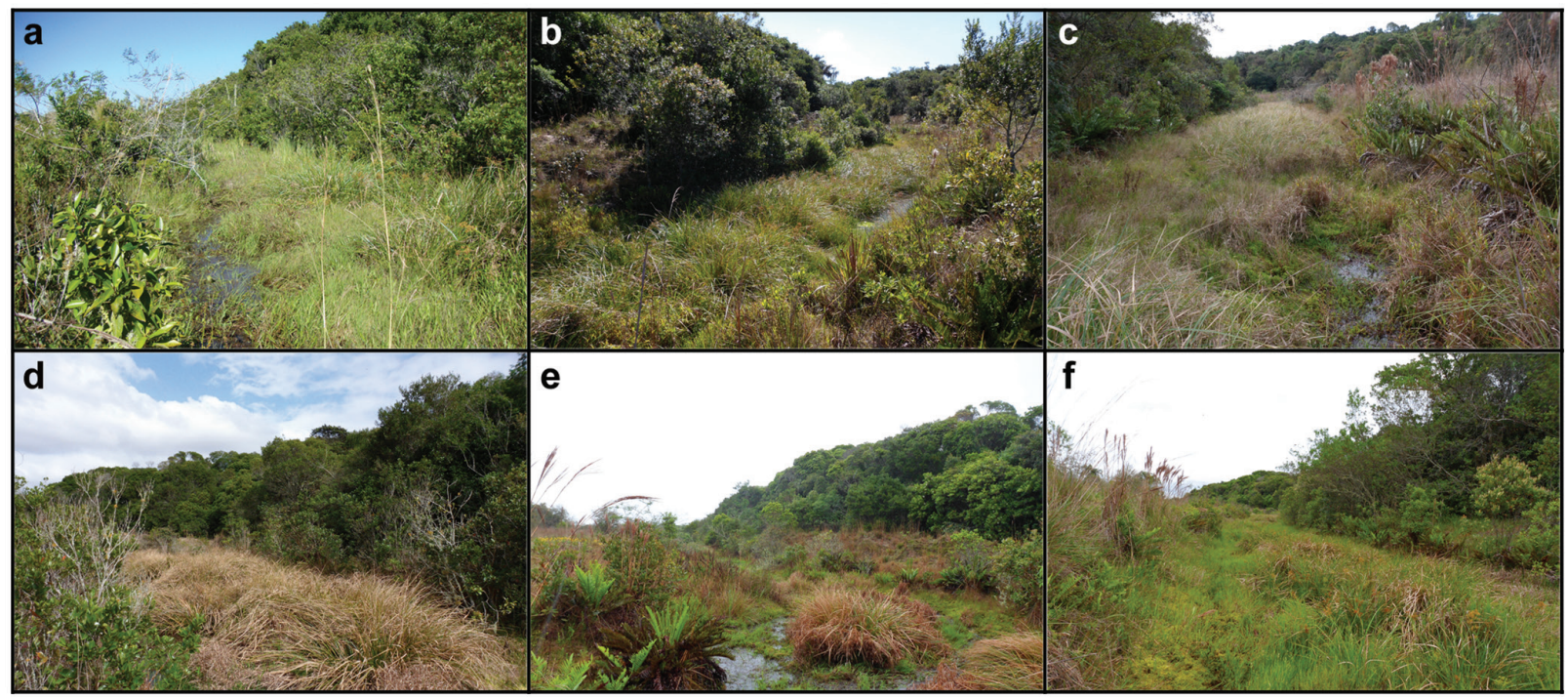

Fig. 2. Sampling area of Atlantirivulus riograndensis. Evidence of seasonal modification of landscape at the collection point at Banhado dos Pachecos wildlife refuge, Viamão, Rio Grande do Sul, Brazil, during the year 2012 (a) Summer in March; Autumn in (b) May and (c) in June; (d) Winter in September; Spring in (e) October and (f) November. 
Sampling. Samples of $A$. riograndensis were captured monthly ( $\mathrm{n}=30$ per month) along the entire year of 2012 , with three sampling per season (southern hemisphere): summer (January, February and March), autumn (April, May and June), winter (July, August and September) and spring (October, November and December). The samples were collected with dip nets ( $500 \times 300 \mathrm{~mm}, 1 \mathrm{~mm}$ mesh) by using different extracts of the water column for sampling from juveniles to adults. The samples were not standardized because was only allowed to collect 30 individuals per month, due to the fact it is a wildlife reserve.

Fish samples were taken with authorization number 52/2012 and register number 395 from the Secretaria do Meio Ambiente do Estado do Rio Grande do Sul (SEMA).

Specimens were euthanized with Eugenol (clove oil), fixed in $10 \%$ formalin while still in the field and kept in the laboratory in $70 \%$ alcohol. The voucher specimens were deposited in the ichthyology collection of the Departamento de Zoologia at the Universidade Federal do Rio Grande do Sul under lots UFRGS 17266 and 17267.

Water temperature was recorded monthly in the sampling site, during collecting expeditions. The monthly amounts of rainfall (in millimeters) and time of sunshine (in hours) was obtained at the $8^{\text {th }}$ District of Meteorology of Porto Alegre (available at Meteorological databank for Education and Research of the National Institute of Meteorology, Brazil, station 83967) (Instituto Nacional de Meteorologia (Inmet), 2013).

Standard length (SL) in $\mathrm{mm}$, total weight (TW) and stomach weight (SW) in grams were recorded for each captured individual, using analytical balance $0.0001 \mathrm{~g}$ accuracy. Individuals were sexed according to microscopic analysis (individuals with gonads without the presence of macroscopically visible oocytes and standard length less than $20 \mathrm{~mm}$ ) and macroscopic gonad analysis in individuals with a standard length greater than $20 \mathrm{~mm}$ (Cavalheiro, 2014) according to dichromatic sexual dimorphism, i.e., the presence of an ocellated black point on the female caudal (Costa, 2009).

Stomach contents were analyzed with a stereomicroscope and food items were identified to the lowest possible taxonomic level (McCafferty, 1998; Mugnai et al., 2010; Segura et al., 2011). The quantification of the items was done by the volumetric method (VO\%) (Hynes, 1950), associated with the frequency of occurrence (FO\%) (Hyslop, 1980). Each food item was quantified through squares occupied on graph paper, with the fixed height of a millimeter.

Data analysis. $\mathrm{FO} \%$ and $\mathrm{VO} \%$ data was explored for the total population (all the individuals for all seasons grouped together) as a descriptive statistic, in hope of providing a general vision of the species' feeding composition, done before investigating sex or ontogenetic influences on the feeding preference of $A$. riograndensis. The $\mathrm{FO} \%$ and $\mathrm{VO} \%$ values and the taxonomic classification of the items found in the stomachs of $A$. riograndensis were utilized to group or separate the foods into food categories according to their characteristics, origin and representation.

Sexual dimorphism in body size (SL) was tested with variance analysis (ANOVA), $\alpha=0.05$, (Zar, 1999) in order to explore for differences in diet between males and females. The ANOVA analysis of residues was employed to verify whether the data obeyed the presupposed normality demanded by the variance test (Legendre \& Legendre, 1998).

The stomach repletion index $(\mathrm{RI}=\mathrm{SW} / \mathrm{TW} * 100)$ (Santos, 1978) was calculated as an indicator of the species' feeding intensity by sex and standard length. The differences in the stomach repletion index between the groups (sex and SL) were tested with covariance analysis, $\alpha=0.05$, (Legendre $\&$ Legendre, 1998) to verify: ontogenetic influence on the variation of this index by standard length; a possible effect of sex on feeding intensity; the effect of interaction between sex and standard length on the feeding intensity of the species.

Seasonal, ontogenetic and sex factors in diet composition were tested by multivariate analysis of variance with permutations (PERMANOVA) (Anderson, 2001), based on a Bray-Curtis dissimilarity matrix (Borcard et al., 2011). PERMANOVA was used to test the composition of the diet because it's a free variance distribution analysis, i.e. it does not require the assumption of normality of data and it permits, additionally, the testing of multiple factors (Anderson, 2001). The Bray-Curtis index was employed in construction of the dissimilarity matrix as it considers both data of presence/absence and of abundance (Borcard et al., 2011). Annual diet variation was tested seasonally (although the collections were done monthly) because the seasons are well defined and characterize four very distinct periods in the place where the species is found: summer, autumn, winter and spring. Ontogenetic influences on diet were inferred with arbitrary distribution of fish in three size categories. These categories were determined according to the grouping of length classes defined by the Sturges rule (Vieira, 1991), in: small sized fish ( $\mathrm{SL} \leq 21.6 \mathrm{~mm}$ ); medium sized fish (SL 21.7 to $32.6 \mathrm{~mm}$ ); large fish (SL $\geq 32.7 \mathrm{~mm}$ ).

Fish frequency (as a function of standard length) in the seasons of the year was tested with ANOVA, $\alpha=0.05$, and subjected to the Tukey HSD post-test (Honestly Significant Difference) with multiple comparisons (Zar, 1999), to check for differences in the size distribution of these fish throughout the collection period. ANOVA residue analysis was utilized to verify the normality of the data (Legendre \& Legendre, 1998).

The test of similarity by percentage (SIMPER) (Clarke \& Warwick, 2001) was used to identify the individual contribution of prey in the tested groups. A canonical correspondence analysis (CCA) (Borcard et al., 2011) was used to visualize patterns in the species' food composition in relation to seasonality and ontogeny, testing the influence of these factors on the distribution of food items consumed by the species in a two-dimensional plane. Statistical tests were performed with the R Project for Statistical Computing program version 3.0.2. 


\section{Results}

Sampling resulted in the capture of 188 females (SL between 10.6 and $44.5 \mathrm{~mm}$ ) and 172 males (SL between 11.9 and $41.3 \mathrm{~mm}$ ) without registering sexual dimorphism in body size in this population (F: $0.76 \mathrm{p}>0.05$ ). Of these individuals, 340 had stomachs containing food (176 females and 164 males).

Stomach contents were grouped into thirteen categories according to their characteristics, origin and representation: Rotifera; Tecameba; Annelida (Oligochaeta and Hirudinea); microcrustaceans (Amphipoda, Copepoda and Cladocera mainly); Autochthonous Chelicerata (Acarina); Allochthonous Chelicerata (Araneae and Acarina); Allochthonous Collembola; Autochthonous Diptera (Ceratopogonidae, Syrphidae, pupae, and other mainly Chironomidae and Culicidae); other autochthonous insects (Coleoptera, Ephemeroptera, Hemiptera, Odonata, Plecoptera, Trichoptera and others); allochthonous insects (Coleoptera, Diptera, Hemiptera, Hymenoptera, Lepidoptera and other); filamentous algae; plant fragments; and organic matter.

Autochthonous food items (VO: 96\% FO: 93\%) were the most relevant to the species, considering all analyzed fish grouping along the year. Autochthonous Diptera was the most consumed food item, corresponding to about half the volume of food ingested by the species with a high frequency of occurrence (VO: 49\% FO: $70 \%$ ). This is why Diptera was separated from the group of other autochthonous insects, the second-most consumed (VO: 26\% FO: $35 \%$ ), followed by microcrustaceans (VO: $13 \%$ FO: 45\%) (Table 1).

PERMANOVA analysis indicated seasonal variations (F: $15.47 \mathrm{p}<0.001$ ), ontogenetic variations (F: $9.64 \mathrm{p}$ $<0.001)$ and sex influences (F: $2.79 p<0.05)$ in the diet of A. riograndensis. These variations were due to differences in the volume of items consumed by the tested groups and not by the number of items in the diet compositions.

Table 1. Volume (VO\%) and frequency of the occurrence (FO\%) of food catagories consumed by Atlantirivulus riograndensis. Individuals collected at the Banhado dos Pachecos wildlife refuge in the city of Viamão, Rio Grande do Sul, Brazil, in 2012.

\begin{tabular}{lcc}
\hline Food Category & VO $(\%)$ & FO $(\%)$ \\
\hline Rotifera & 0.02 & 0.28 \\
Tecameba & 0.19 & 3.06 \\
Annelida & 1.92 & 9.72 \\
Microcrustaceans & 13.13 & 45.28 \\
Autochthonous Chelicerata & 0.09 & 1.11 \\
Allochthonous Chelicerata & 0.74 & 6.11 \\
Allochthonous Collembola & 0.14 & 0.83 \\
Autochthonous Diptera & 48.97 & 70.28 \\
Other autochthonous insects & 26.40 & 35.00 \\
Allochthonous insects & 3.22 & 6.39 \\
Filamentous algae & 0.43 & 1.39 \\
Plant fragments & 3.30 & 8.06 \\
Organic matter & 1.47 & 6.39 \\
\hline
\end{tabular}

Dissimilarity in the diet of males and females (62.98\%), according to SIMPER analysis, is due mainly to differences in the volumes of items consumed (Table 2). The food item autochthonous Diptera represented $54.52 \%$ of the annual volume of food in females, while for males it represented $41.33 \%$ (Table 3). Males and females consumed respectively $29.86 \%$ and $23.89 \%$ of the categories "other autochthonous insects" and $15.06 \%$ and $11.73 \%$ of the microcrustaceans (Table 3). The stomach repletion index indicates that females ingested larger amounts of food than males in all standard lengths (F: $15.89 \mathrm{p}<0.001$ ) (Fig. 3).

Table 2. SIMPER analysis with paired comparisons of the contribution (by percentage of dissimilarity) in the diet of Atlantirivulus riograndensis of the main food items consumed in relation to sex, seasonality, and ontogeny. Individuals collected at the Banhado dos Pachecos wildlife refuge in the city of Viamão, Rio Grande do Sul, Brazil, in 2012. Standard Length (SL).

\begin{tabular}{|c|c|c|c|c|}
\hline Category & $\begin{array}{c}\text { Average } \\
\text { Dissimilarity (\%) }\end{array}$ & $\begin{array}{l}\text { Autochthonous } \\
\text { Diptera (\%) }\end{array}$ & $\begin{array}{c}\text { Microcrustaceans } \\
(\%)\end{array}$ & $\begin{array}{c}\text { Other autochthonous } \\
\text { insects }(\%)\end{array}$ \\
\hline Females $(n=176)$ and males $(n=164)$ & 62.98 & 35.70 & 20.09 & 23.82 \\
\hline Summer $(\mathrm{n}=85)$ and fall $(\mathrm{n}=82)$ & 71.06 & 30.48 & 22.84 & 22.13 \\
\hline Summer $(\mathrm{n}=85)$ and winter $(\mathrm{n}=89)$ & 63.67 & 38.73 & 19.96 & 24.95 \\
\hline Spring $(\mathrm{n}=84)$ and summer $(\mathrm{n}=85)$ & 67.21 & 33.08 & 17.27 & 28.48 \\
\hline Fall $(n=82)$ and winter $(n=89)$ & 59.49 & 40.02 & 25.29 & 14.43 \\
\hline Fall $(n=82)$ and spring $(n=84)$ & 69.81 & 33.50 & 20.45 & 23.43 \\
\hline Spring $(n=84)$ and winter $(n=89)$ & 53.99 & 39.65 & 15.23 & 30.39 \\
\hline $\mathrm{SL} \leq 21.6(\mathrm{n}=129)$ and SL 21.7 to $32.6(\mathrm{n}=187)(\mathrm{mm})$ & 62.13 & 35.47 & 23.35 & 22.04 \\
\hline $\mathrm{SL} \leq 21.6(\mathrm{n}=129)$ and $\mathrm{SL} \geq 32.7(\mathrm{n}=24)(\mathrm{mm})$ & 73.63 & 30.61 & 19.88 & 28.54 \\
\hline SL 21.7 to $32.6(n=187)$ and $S L \geq 32.7(n=24)(\mathrm{mm})$ & 70.18 & 34.17 & 11.12 & 30.48 \\
\hline
\end{tabular}


Table 3. Annual volume in percentage of the main food items consumed by Atlantirivulus riograndensis in relation to sex, seasonality, and ontogeny. Individuals collected at the Banhado dos Pachecos wildlife refuge in the city of Viamão, Rio Grande do Sul, Brazil, in 2012. The values in bold represent the category in which each item was consumed with the highest percentages. Standard Length (SL).

\begin{tabular}{lccc}
\hline Category & Autochthonous Diptera (\%) & Microcrustaceans (\%) & Other autochthonous insects (\%) \\
\hline Females (n=176) & $\mathbf{5 4 . 5 2}$ & 11.73 & 23.89 \\
Males (n=164) & 41.33 & $\mathbf{1 5 . 0 6}$ & $\mathbf{2 9 . 8 6}$ \\
Summer (n=85) & 32.25 & 16.66 & $\mathbf{4 0 . 3 3}$ \\
Fall (n=82) & 44.06 & $\mathbf{2 2 . 8 8}$ & 12.02 \\
Winter (n=89) & $\mathbf{6 9 . 5 7}$ & 11.30 & 15.31 \\
Spring $(\mathrm{n}=84)$ & 48.04 & 3.91 & 35.98 \\
SL $\leq 21.6(\mathrm{~mm})(\mathrm{n}=129)$ & 45.38 & $\mathbf{2 4 . 5 0}$ & 18.46 \\
SL 21.7 to 32.6 (mm) $(\mathrm{n}=187)$ & $\mathbf{5 2 . 3 2}$ & 9.93 & 27.72 \\
SL $\geq 32.7(\mathrm{~mm})(24)$ & 35.34 & 2.14 & 40.78 \\
\hline
\end{tabular}

Feeding intensity varied according to ontogeny. We observed an inverse relationship between the standard length and the values of the stomach repletion index for both $\operatorname{sex}\left(\mathrm{F}: 116.71 \mathrm{p}<0.001 \mathrm{R}^{2}\right.$ : 0.27), indicating that females and males behave similarly (F: 0.124 p: $0.72 \mathrm{R}^{2}$ : 0.27 ), proportionally decreasing food intake as they grow (Fig. 3).

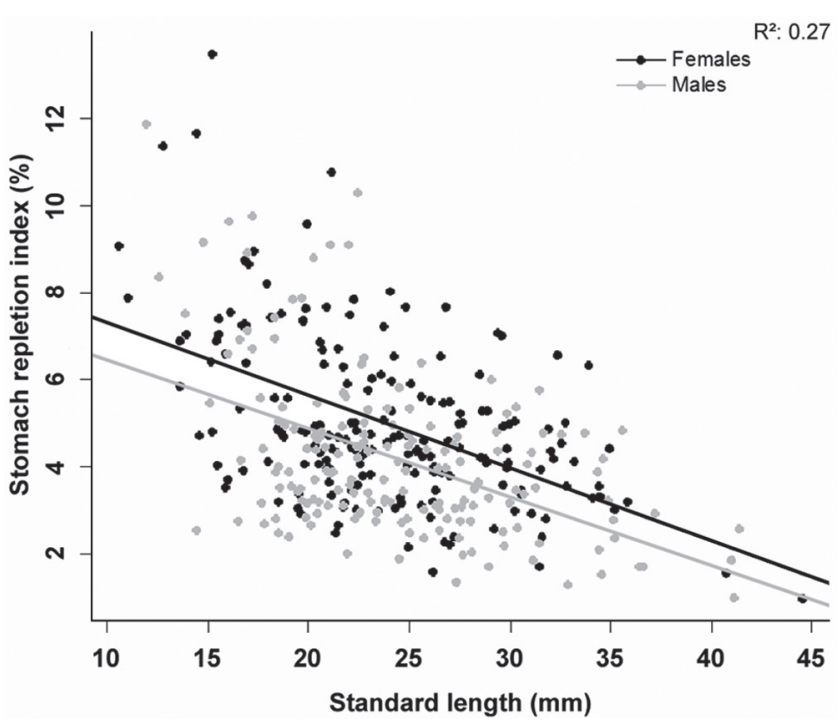

Fig. 3. Index of stomach fullness in relation to standard length. Ontogenetic analysis of the Atlantirivulus riograndensis feeding intensity by sex, collected the Banhado dos Pachecos wildlife refuge, in the city of Viamão, Rio Grande do Sul, Brazil, in 2012.

Individuals with a standard length of less than $21.7 \mathrm{~mm}$ consumed microcrustaceans, which corresponded to $24.5 \%$ of the volume of food ingested by this size category (Table 3). Microcrustaceans represented $9.93 \%$ of medium-sized fish diet volume (SL: 21.7 to $32.6 \mathrm{~mm}$ ) and only $2.14 \%$ for larger fish ( $\mathrm{SL} \geq 32.7)$. Larger fish ate a higher percentage of Copepoda, and Cladocera was more consumed by the smaller fish (Table 4).
Table 4. Diversity and anual volume of microcrustations consumed by Atlantirivulus riograndensis according to onotgeny. Individuals collected at the Banhado dos Pachecos wildlife refuge in the city of Viamão, Rio Grande do Sul, Brazil, in 2012. The values in bold represent the category in which each item was consumed with the highest percentages. Standard Length (SL).

\begin{tabular}{lccc}
\hline Category & Amphipoda & Cladocera & Copepoda \\
\hline SL $\leq 21.6(\mathrm{~mm})(\mathrm{n}=129)$ & 0.52 & 85.30 & 14.18 \\
SL 21.7 to 32.6 $(\mathrm{mm})(\mathrm{n}=187)$ & $\mathbf{8 . 5 5}$ & $\mathbf{6 4 . 9 9}$ & 26.46 \\
SL $\geq 32.7(\mathrm{~mm})(\mathrm{n}=24)$ & 0.00 & 36.36 & $\mathbf{6 3 . 6 4}$ \\
\hline
\end{tabular}

The decrease in microcrustacean consumption during ontogeny is accompanied by the increase in consumption of "other autochthonous insects". The consumption of autochthonous Diptera remains high in all size categories, although it is more representative in fish of medium length, an intermediate range between an insectivorous diet and a diet of zooplankton (Table 3; Fig. 4).

The largest dissimilarity in diet with regards to ontogeny was found between the smallest and largest fish (73.63\%), attributed to variation in the consumption of insects (Table 2). Fish longer than $32.7 \mathrm{~mm}$ standard length increased the trophic niche with a more varied diet, with $40 \%$ of the volume of food eaten assigned to "other autochthonous insects". This size range of $A$. riograndensis did not consume Rotifera, Tecameba and water mites (autochthonous Chelicerata), associated to the diet of small fish as evidenced in the canonical correspondence analysis (Fig. 4).

Seasonality is well marked in the feeding of $A$. riograndensis with average dissimilarity values above 50\% for all the seasons (Table 2).

Larger fish that showed a greater diversity in food composition occurred most often in spring and summer (F: 2.74 p: 0.042) (Fig. 5), seasons that correspond with the species' reproductive period (Cavalheiro, 2014). The canonical correspondence analysis reveals a greater diversity of food items plotted between these seasons and the larger fish influencing this food composition (Fig. 4). 


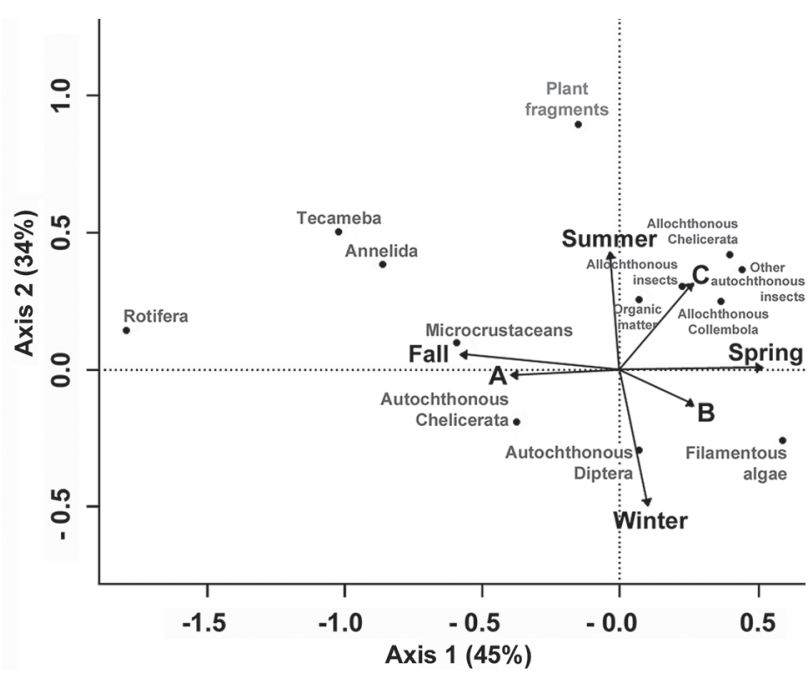

Fig. 4. Canonical Correspondence Analysis (CCA) of food composition of Atlantirivulus riograndensis representing the importance of seasonal and ontogenetic variables, with $\mathrm{p}<0$ :05, according to the length of arrows associated with each vector. Individuals collected at the Banado dos Pachecos wildlife refuge, Viamão, Rio Grande do Sul, Brazil, in 2012. A: $\leq 21.6 \mathrm{~mm}$ Standard length; B: Standard length from 21.7 to $32.6 \mathrm{~mm}$; C: Standard length $\geq 32.7 \mathrm{~mm}$.

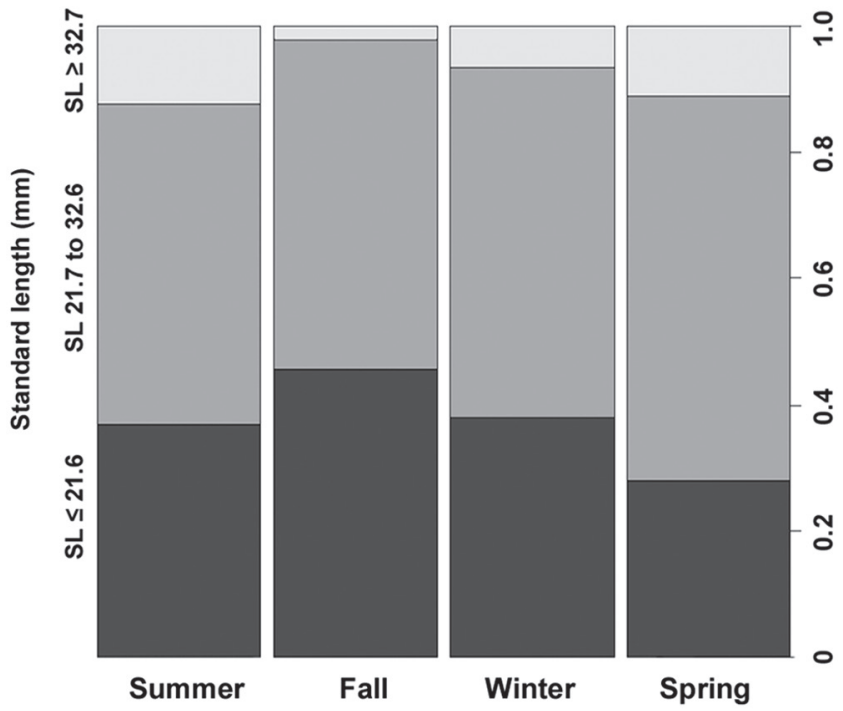

Fig. 5. Seasonal distribution of Atlantirivulus riograndensis by frequency of standard length (SL). Individuals collected at the Banhado dos Pachecos wildlife refuge, Viamão, Rio Grande do Sul, Brazil, in 2012.

\section{Discussion}

Dominance of autochthonous items in the diet revealed an expected standard for the feeding spectrum of $A$. riograndensis, corroborating the initial hypothesis that the species follows the pattern of other rivulids (Laufer et al., 2009; Goncalves et al., 2011; Keppeler et al., 2013).
Benthic invertebrates, especially immature insects, represent an important food resource for continental fish fauna and the high consumption of Chironomidae observed in $A$. riograndensis in this study (common among small fish) may be associated with their abundance in many aquatic environments (Lowe-McConnell, 1999; Higuti \& Takeda, 2002; Hahn \& Fugi, 2007). These autochthonous habits indicate a strong dependency relationship of $A$. riograndensis with the biotic integrity of the water body it inhabits, reinforcing the need for preservation of aquatic environments and their surrounding areas, including riparian forests (due to the allochthonous items also utilized by the species), in the remaining natural areas of Pampa.

Autochthonous items were crucial in the diet of three other species of Atlantirivulus: A. haraldsiolii which is considered omnivorous (Abilhoa et al., 2010b), A. santensis consuming immature aquatic insects (Contente \& Stefanoni, 2010), and $A$. lueling $i$ which consumed $66 \%$ of food items of autochthonous origin and of these, Chironomidae larvae corresponded to the principal item (Abilhoa et al., 2010a).

Consumption of autochthonous insects and microcrustaceans as major components of the diet is reported in Brazil for: the non-annual rivulid Melanorivulus pictus (Cerrado biome) (Shibatta \& Bennemann, 2003); the annual Simpsonichthys boitonei (in an ecological reserve of Cerrado) (Shibatta \& Rocha, 2001); the annual Cynopoecilus fulgens (in an ecological reserve in the Pampa biome) (Keppeler et al., 2013); the annual Cynopoecilus melanotaenia (Pampa biome) (Gonçalves et al., 2011).

Preference for autochthonous Diptera (mainly Chironomidae) followed by the category "other autochthonous insects" indicates a specialist trend of insectivorous feeding behavior of $A$. riograndensis, perceived at a higher intensity throughout the species' somatic growth.

Fish with specialist tendencies associated with more stable habitats in regards to water variation (Poff \& Allan, 1995; Hinojosa-Garro et al., 2013) are more easily detected when the food source is abundant compared to generalist fish associated with scarce food resources (Gerking, 1994).

Sex variations in diet of $A$. riograndensis were due to differences in the volume of items consumed and not by the number of items. Sex differences in diet was also registered for the annual rivulid Austrolebias luteoflammulatus with greater diversity of food items in the diet of males (Laufer et al., 2009), while in the annual rivulids C. melanotaenia (Gonçalves et al., 2011) sex influences on dietary were not reported. The higher food consumption in female $A$. riograndensis in this study corresponds to the same pattern identified in S. boitonei (Shibatta \& Rocha, 2001). The authors explained these differences considering the social behavior of this annual species and the hypothesis that males would spend less time feeding and more time defending the territory or showing off for the females, although the food composition between sexes was very similar (Shibatta \& Rocha, 2001). 
Ontogenetic influence on the dietary composition of $A$. riograndensis indicates that large and small fish consume different foods. The seasonal effects detected in the species' diet suffer, therefore, the influence of the presence of small or large fish in greater or smaller quantities due to reproductive events. Smaller individuals consumed autochthonous Diptera considerably, though they behaved in a zooplanktivorous way- ingesting a larger number of microcrustaceans when compared to other stages of development of the species (which showed a broader feeding spectrum throughout somatic growth). In the same way, the consumption of microcrustaceans is higher in the winter, when the frequency of small fish is greater, immediately following the species' reproduction that, according to Cavalheiro (2014), occurs between the months of August and March.

In Atlantirivulus, A. luelingi and A. santensis showed no ontogenetic influences on food composition, while in $A$. haraldsiolii juveniles mainly consumed immature aquatic insects and water mites and adults preferred water mites, plant fragments and Formicidae (Abilhoa et al., 2010a, 2010b; Contente \& Stefanoni, 2010). In the Rivulidae family ontogenetic influences were reported in the feeding of annual Austrolebias cheradophilus, C. melanotaenia and C. fulgens (Laufer et al., 2009; Keppeler et al., 2013).

For $A$. riograndensis, ontogenetic variations in diet composition followed a gradient of transition from a diet richer in zooplankton to one more insectivorous. Expansions in the feeding spectrum and changes in prey consumed are expected for some species of fish throughout their lives (Winemiller, 1989; Gerking, 1994; Houde, 1997; Abelha et al., 2001).

The type of microcrustaceans ingested changes during the development of $A$. riograndensis. As expected for freshwater species, the dependence on Cladocera is greater than that of Copepods, especially in larval stages (Gerking, 1994).

Selectivity of prey during foraging and the volume of food consumed by the species are related to: the availability of food, variable energy needs, energy expenditure used in capturing prey, the nutritional capabilities of these prey, the reproductive period, abiotic conditions, social behavior, the rate of predation, places of refuge, the activities of predators and prey, etc. (Nikolsky, 1963; Abelha et al., 2001; Barreto \& Aranha, 2006; Gomiero \& Braga, 2008; Gimenes et al., 2013).

The decrease in the relative amount of food consumed by $A$. riograndensis during somatic growth cannot therefore be associated with one these attributes in isolation. This is because the energetic capacity of the consumed prey may be variable, since diet composition changes from microcrustaceans to autochthonous insects during ontogeny. Furthermore, this species has a very early oocyte maturation (Cavalheiro, 2014), which could indicate a high energy necessity for investment in somatic growth in the first stages of life before starting the phase of reproductive development. In comparison, the killifish Austrolebias cheradophilus, A. luteoflammulatus, Austrolebias viarius e C. melanotaenia present an increase in energy demand during somatic growth and a positive relation between body size and the richness of prey, the number of base energetic resources, and the uniformity in the use of the prey, to compensate the lesser availability of energy with each increase in trophic position (Arim et al., 2010). In the case of fish species with small body sizes, Segura et al. (2015) suggest that gape limitations influence prey consumption, while for bigger fish the trophic position is influenced by energetic restrictions of superior trophic levels.

Seasonal effects perceived in the $\operatorname{diet}$ of $A$. riograndensis are commonly recorded for several freshwater species (Winemiller, 1990; Polis \& Winemiller, 1996; Winemiller \& Jepsen, 1998; Hahn \& Fugi, 2008). However, it was not possible to clearly identify whether the seasonal effect of the species' diet (indicated by the existence of a difference in dietary composition throughout the year and detected by PERMANOVA) is more related to seasonal changes in habitat, due to the presence of well defined seasons at the research site, or to the effect of its reproductive cycle.

Seasonal variations at the collection point could be observed both by changes in the water levels along the flooded strip (which showed greater depth in the winter months when the rains were more intense) and also in the varied abundance and richness of vegetation composition. In the coldest period of the year (because of the frost and low temperatures recorded for the region) drier and in some months less abundant vegetation was observed, though its gradual recovery was observed in the early spring to summer. Therefore, the seasonal differences in food composition are considered an effect of the combined influence of changes in habitat and reproductive cycle. For ontogenetic differences in diet, on the other hand, only somatic growth of individuals in considered an effect, inferred with a basis in standard length.

Compared to A. riograndensis, Atlantirivulus luelingi showed seasonal food differences - although these were not associated with the quantity of rain (which defines the seasons in the area in which the study was conducted) (Abilhoa et al., 2010a). Meanwhile, for Cynopoecilus fulgens there is a record of greater prey diversity in the summer and spring with more intense ingestion of Cladocera in summer and autumn (Keppeler et al., 2013), which is the same pattern identified in A. riograndensis, except for the consumption of microcrustaceans in summer as a main food item.

Variation between the consumption of autochthonous Diptera and the category "other autochthonous insects" was more balanced in the spring for $A$. riograndensis. In the summer the "other autochthonous insects" category dominated in terms of volume. In the spring and summer, water temperatures were higher (averages: 21 and $23{ }^{\circ} \mathrm{C}$ ), there was more sunshine (averages: 231 and 262 hours) 
and less rainfall (averages: 114 and $143 \mathrm{~mm}$ ). There was a gradual increase in food item diversity during the transition of these seasons (spring to summer), accompanied by changes in the landscape.

In the fall, high consumption levels of microcrustaceans may be linked to the presence of greater numbers of small fish (SL $\leq 21.6 \mathrm{~mm}$ ), as these individuals are primarily responsible for the ingestion of this food category. This season corresponds to the months following the species' reproductive period. In the fall the average water temperature was $19{ }^{\circ} \mathrm{C}$, the average sunshine was 162 hours and the average rainfall was $48 \mathrm{~mm}$. Winter, in turn, with the lowest water temperature (average $16{ }^{\circ} \mathrm{C}$ ), shorter sunshine (average: 147 hours) and highest rainfall (average $171 \mathrm{~mm}$ ) showed a peak in autochthonous Diptera consumption and (together with the fall) the smallest diversity of diet items.

In sum, hypothesis of a preferably autochthonous diet and the hypothesis of seasonal effects on the species' diet influenced by annual reproductive events, due to ontogenetic influences in the feeding composition of the A. riograndensis were corroborated. Specialist trend for insectivory increases with ontogeny, although feeding intensity decreases along the somatic growth of the species. Sex differences in diet are characterized by higher feeding intensity in females. Seasonality reflects a greater diversity of prey in the spring and summer seasons in which the presence of larger fish (during the reproductive period) was most frequent. Seasonal changes in the vegetation composition and water levels of the habitat of $A$. riograndensis were noted, possibly influencing (directly or indirectly) available food resources and hence its diet.

\section{Acknowledgements}

We thank professors Dr. Luiz Roberto Malabarba and Dr. Carla Ferreira Rezende for the revision and suggestions to this article; Ms. Tatiana Schmidt Dias for her contributions to the initial project of this study; and our colleagues at the Ichthyology Lab of the Federal University of Rio Grande do Sul for help with the samples from the field. We thank by a research grant provided by the Coordenação de Aperfeiçoamento de Pessoal de Nível Superior (CAPES) to the first author and by a productivity grant given by the Conselho Nacional de Desenvolvimento Científico e Tecnológico - CNPq to the second author.

\section{References}

Abelha, M. C. F., A. A. Agostinho \& E. Goulart. 2001. Plasticidade trófica em peixes de água doce. Acta Scientiarum, 23: 425-434.

Abilhoa, V., J. R. S. Vitule \& H. Bornatowski. 2010a. Feeding ecology of Rivulus luelingi (Aplocheiloidei: Rivulidae) in a Coastal Atlantic Rainforest stream, southern Brazil. Neotropical Ichthyology, 8: 813-818.
Abilhoa, V., J. R. S. Vitule, H. Bornatowski, F. B. Lara, G. U. Kohler, L. Festti, W. P. D. Carmo \& I. K. Ribeiro. 2010 b. Effects of body size on the diet of Rivulus haraldsiolii (Aplocheiloidei: Rivulidae) in a coastal Atlantic Rainforest island stream, southern Brazil. Biotemas, 23: 59-64.

Accordi, I. A. 2008. Ecologia e conservação de aves em ambientes costeiros do Rio Grande do Sul. Unpublished Ph.D. Dissertation, Universidade Federal do Rio Grande do Sul, Porto Alegre, 111p.

Anderson, M. J. 2001. A new method for non-parametric multivariate analysis of variance. Austral Ecology, 26: 32-46.

Arim, M., S. R. Abades, G. Laufer, M. Loureiro \& P. A. Marquet. 2010. Food web structure and body size: trophic position and resource acquisition. Oikos, 119: 147-153.

Barreto, A. P. \& J. M. R. Aranha. 2006. Alimentação de quatro espécies de Characiformes de um riacho da floresta Atlântica, Guaraqueçaba, Paraná, Brasil. Revista Brasileira de Zoologia, 23: 779-788.

Borcard, D., F. Gillet \& P. Legendre. 2011. Numerical ecology with R. New York, Springer, 306p.

Cavalheiro, L. W. 2014. Biologia alimentar e reprodutiva de Atlantirivulus riograndensis (Costa \& Lanés, 2009) (Cyprinodontiformes: Rivulidae) no Refúgio da Vida Silvestre Banhado dos Pachecos, Rio Grande do Sul, Brasil. Unpublished Ph.D. Dissertation, Universidade Federal do Rio Grande do Sul, Porto Alegre, 68p.

Clarke, K. R. \& R. M. Warwick. 2001. Change in marine communities: an approach to statistical analysis and interpretation. 2nd ed. Plymouth, Plymouth/Primer-E.

Contente, R. \& M. Stefanoni. 2010. Diet of the Atlantic rainforest killifish Rivulus santensis (Rivulidae, Cyprinodontiformes) in southeastern Brazil. Journal of Applied Ichthyology, 26: 930-932.

Costa, W. J. E. M. 2009. Peixes aploqueilóideos da Mata Atlântica brasileira: História, diversidade e conservação. Rio de Janeiro, Museu Nacional, 171p.

Costa, W. J. E. M. 2011. Phylogenetic position and taxonomic status of Anablepsoides, Atlantirivulus, Cynodonichthys, Laimosemion and Melanorivulus (Cyprinodontiformes: Rivulidae). Ichthyological Exploration of Freshwaters, 22: 233-249.

DeAngelis, D. L., J. C. Trexler, C. Cosner, A. Obaza \& F. Jopp. 2010. Fish population dynamics in a seasonally varying wetland. Ecological Modelling, 221: 1131-1137.

Eschmeyer, W. N. \& J. D. Fong. (Eds.). 2015. Catalog of fishes. San Francisco, CA, California Academy of Sciences. Available from: http://researcharchive.calacademy.org/research/ ichthyology/catalog/SpeciesByFamily.asp (12 Feb 2015).

Fundação Zoobotânica do Rio Grande do Sul (FZB). 2014. Avaliação do Estado de Conservação de Espécies - Fauna RS - 2014. Porto Alegre, FZB. Available from: http://www. liv.fzb.rs.gov.br/livlof/?id_modulo=1\&id_uf $=23 \&$ ano $=2012$ (16 Mar 2015).

Gerking, S. D. 1994. Feeding ecology of fish. San Diego, CA, Academic Press, 416p.

Gimenes, M. F., R. Fugi, A. Isaac \& M. R. Silva. 2013. Spatial, seasonal and ontogenetic changes in food resource use by a piscivore fish in two Pantanal lagoons, Brazil. Neotropical Ichthyology, 11: 163-170.

Gomiero, L. M. \& F. M. S. Braga. 2008. Feeding habits of the ichthyofauna in a protected area in the State of São Paulo, southeastern Brazil. Biota Neotropica, 8: 41-47. 
Gonçalves, C. S., U. P. Souza \& M. V. Volcan. 2011. The opportunistic feeding and reproduction strategies of the annual fish Cynopoecilus melanotaenia (Cyprinodontiformes: Rivulidae) inhabiting ephemeral habitats on southern Brazil. Neotropical Ichthyology, 9: 191-200.

Hahn, N. S. \& R. Fugi. 2007. Alimentação de peixes em reservatórios brasileiros: alterações e consequências nos estágios iniciais do represamento. Oecologia Brasiliensis, 11: 469-480.

Hahn, N. S. \& R. Fugi. 2008. Environmental changes, habitat modifications and feeding ecology of freshwater fish. Pp. 3565. In: Cyrino, J. E. P., D. P. Bureau \& B. G. Kapoor (Eds.). Feeding and digestive functions of fishes. Enfield, $\mathrm{NH}$, Science Publishers.

Higuti, J. \& A. M. Takeda. 2002. Spatial and temporal variation in densities of chironomid larvae (Diptera) in two lagoons and two tributaries of the upper Paraná River floodplain, Brazil. Brazilian Journal of Biology, 62: 807-818.

Hinojosa-Garro, D., J. Arceo-Gómez, L. Zambrano \& L. H. Escalera-Vázquez. 2013. Fish diet composition in permanent and semi-permanent pools in tropical wetlands of the Yucatan Peninsula. Neotropical Ichthyology, 11: 881-890.

Houde, E. D. 1997. Patterns and consequences of selective processes in teleost early life histories. Pp. 173-196. In: Chambers, R. C. \& E. A. Trippel (Eds.). Early life history and recruitment in fish populations. London. 1st ed. Chapman \& Hall. (Fish and fisheries series, 21).

Hynes, H. B. N. 1950. The food of fresh-water sticklebacks (Gasterosteus aculeatus and Pygosteus pungitius), with a review of methods used in studies of the food of fishes. Journal of Animal Ecology, 19: 36-58.

Hyslop, E. J. 1980. Stomach contents analysis-a review of methods and their application. Journal of Fish Biology, 17: 411-429.

Instituto Nacional de Meteorologia (INMET). 2013. Banco de Dados Meteorológicos para Ensino e Pesquisa. Instituto Nacional de Meteorologia. Available from: http://www.inmet. gov.br/portal/index.php?r=bdmep/bdmep (05 Dec 2013).

Keppeler, F. W., L. E. K. Lanés, A. S. Rolon, C. Stenert \& L. Maltchik. 2013. The diet of Cynopoecilus fulgens Costa, 2002 (Cyprinodontiformes: Rivulidae) in Southern Brazil wetlands. Italian Journal of Zoology, 80: 291-302.

Lake, P. S. 2003. Ecological effects of perturbation by drought in flowing waters. Freshwater Biology, 48: 1161-1172.

Laufer, G., M. Arim, M. Loureiro, J. M. Piñeiro-Guerra, S. Clavijo-Baquet \& C. Fagúndez. 2009. Diet of four annual killifishes: an intra and interspecific comparison. Neotropical Ichthyology, 7: 77-86.

Legendre, P. \& L. Legendre. 1998. Numerical ecology. 2nd ed. Amsterdam, Elsevier, 853p. (Developments in environmental modelling, 20).

Lowe-McConnell, R. H. 1999. Estudos ecológicos de comunidades de peixes tropicais. Tradução: Anna Emília A. de M. Vazzoler, Ângelo Antonio Agostinho, Patrícia T. M. Cunningham. São Paulo, Edusp, 534p. (Coleção Base). Título original: Ecological studies in tropical fish communities.

McCafferty, W. P. 1998. Aquatic entomology: the fishermen's and ecologist's illustrated guide to insects and their relatives. Illustrations by Arwin V. Provonsha. Boston, Jones and Bartlett Publishers, 448p.
Mas-Martí, E., E. García-Berthou, S. Sabater, S. Tomanova \& I. Muñoz. 2010. Comparing fish assemblages and trophic ecology of permanent and intermittent reaches in a Mediterranean stream. Hydrobiologia, 657: 167-180.

Mugnai, R., J. L. Nessimian \& D. F. Baptista. 2010. Manual de identificação de macroinvertebrados aquáticos do estado do Rio de Janeiro para atividades técnicas, de ensino e treinamento em programas de avaliação da qualidade ecológica dos ecossistemas lóticos. Rio de Janeiro, Technical Books, 173p.

Nikolsky, G. V. 1963. The ecology of fishes. Translated from the Russian by L. Birkett. London, Nova York, Academic Press, $352 \mathrm{p}$.

Pillar, V. P., S. C. Müller, Z. M. S. Castilhos \& A. V. A. Jacques (Eds.). 2009. Campos Sulinos: conservação e uso sustentável da biodiversidade. Brasília, DF, Ministério do Meio Ambiente, $403 \mathrm{p}$.

Poff, N. L. \& J. D. Allan. 1995. Functional organization of stream fish assemblages in relation to hydrological variability. Ecology, 76: 606-627.

Polis, G. A. \& K. O. Winemiller (Eds.). 1996. Food webs: integration of patterns \& dynamics. New York, Chapman \& Hall, 472p.

Santos, E. P. 1978. Dinâmica de populações aplicada à pesca e piscicultura. São Paulo, Hucitec/Edusp, 129p.

Segura, A. M., V. Franco-Trecu, P. Franco-Fraguas \& M. Arim. 2015. Gape and energy limitation determine a humped relationship between trophic position and body size. Canadian Journal of Fisheries and Aquatic Sciences, 72: 198-205.

Segura, M. O., F. Valente-Neto \& A. A. Fonseca-Gessner. 2011. Chave de famílias de Coleoptera aquáticos (Insecta) do Estado de São Paulo, Brasil. Biota Neotropica, 11: 393-412.

Shibatta, O. A. \& S. T. Bennemann. 2003. Plasticidade alimentar em Rivulus pictus Costa (Osteichthyes, Cyprinodontiformes, Rivulidae) de uma pequena lagoa em Brasília, Distrito Federal, Brasil. Revista Brasileira de Zoologia, 20: 615-618.

Shibatta, O. A. \& A. J. A. Rocha. 2001. Alimentação em machos e fêmeas do pirá-brasília, Simpsonichthys boitonei Carvalho (Cyprinodontiformes, Rivulidae). Revista Brasileira de Zoologia, 18: 381-385.

Vieira, S. 1991. Introdução à bioestatística. 2ed. rev. e ampl. Rio de Janeiro, Ed Campus, 203p.

Winemiller, K. O. 1989. Patterns of variation in life history among South American fishes in seasonal environments. Oecologia, 81: $225-241$.

Winemiller, K. O. 1990. Spatial and temporal variation in tropical fish trophic networks. Ecological Monographs, 60: 331-367.

Winemiller, K. O. \& D. B. Jepsen. 1998. Effects of seasonality and fish movement on tropical river food webs. Journal of Fish Biology, 53(suppl. A.): 267-296.

Wootton, R. J. 1990. Ecology of teleost fishes. London, Chapman $\&$ Hall, 404p. (Fish and fisheries, 1).

Zar, J. H. 1999. Biostatistical analysis. 4th ed. Upper Saddle River, NJ, Prentice Hall, 123p.

Submitted May 18, 2015

Accepted November 22, 2015 by Franco Teixeira de Mello 